\title{
İlkokul 3. ve 4. Sınıf Öğrencilerinin Çocuk Hakları Konusundaki Bilinç Düzeylerinin Belirlenmesi: Bir Ölçek Geliştirme Çalışması*
}

\section{The Definition Of The Consciousness Level Of 3rd And 4th Grade Primary School Studens About Child Rights: A Scale Development Work}

\author{
Kaya Tuncer Çağlayan, ${ }^{a}$ Mehmet Şaban Akgül ${ }^{\text {b** }}$
}

${ }^{a}$ Prof.Dr.Kaya Tuncer Çağlayan, Ondokuz Mayıs Üniversitesi, Eğitim Fakültesi, Temel Eğitim Bölümü, 55105, Samsun/Türkiye. ORCID: 0000-0002-9834-8034

`Öğr.Gör.Dr.,Mehmet Şaban Akgül, Tokat Gaziosmanpaşa Üniversitesi, Reşadiye MYO, Çocuk Bakımı ve Gençlik Hizmetleri Bölümü, 60700,

Tokat/Türkiye.

ORCID: 0000-0002-7257-5458

MAKALE BILLGISİ

Makale Geçmişi:

Başvuru tarihi: 28 Şubat 2019

Kabul tarihi: 01 Nisan 2019

Anahtar Kelimeler:

Çocuk Hakları

Ölçek Geliștirme

İlkokul

\section{A R T ICLE INFO}

\section{Article history:}

Received 28 February 2019

Received in revised form 21 March 2019

Accepted 01 April 2019

Keywords:

Child Rights

Scale Development

Primary School
Düzeltme tarihi: 21 Mart 2019

ÖZ

Bu çalışmada, ilkokul 3. ve 4. Sınıf öğrencilerinin çocuk hakları konusundaki bilinç düzeylerini ölçmeye yönelik geçerli ve güvenilir bir ölçek geliştirmek amaçlanmıştır. Bu araştırma bir ölçek geliştirme çalışması olup, araştırma sürecinde nicel araştırma yöntemlerinden olan tarama yöntemi kullanılmıştır. Araştırma kapsamında geliştirilen ölçek 3 faktör ve 18 maddeden oluşmaktadır. Araştırma sırasında 2017-2018 eğitim öğretim yılında Tokat il genelindeki çeşitli okullarda 3 . ve 4. Sınıfta öğrenim gören 501 öğrenci ile çalışılmıştır. Geçerlik aşamasında; kapsam, görünüş ve yapı geçerliği incelenmiştir. Güvenirlik aşamasında; iç tutarlık katsayısı, \%27’lik alt grup üst grup ortalamaları hesaplanmıs olup, faktörler arası iliskiler ve ölçek maddelerinin \%27 lik alt grup üst grup ilişkileri incelenmiştir. Araştırma sonucunda geçerliliği ve güvenirliği sağlanmış "İlkokul 3. ve 4. Sınıf Öğrencilerinin Cocuk Hakları Konusundaki Görüșlerinin Belirlemesi” ne yönelik 3 alt boyutlu ve 18 maddeye sahip bir ölçek geliştirilmiştir.

\section{A B S T R AC T}

In this study, it was aimed to improve a reliable and a valid scale for measuring the consciousness levels of 3rd and 4th grade primary school student about child rights. This research is a scale improvement study and in the survey process scanning method, one of the quantitive research methods, was used. The scale improved under the scope of research is consisted of 3 factors and 18 items. During the research process we studied with 501 primary school students of 3rd and 4th grades in 2017 - 2018 academic year in the Tokat province-wide. At the validity stage; content validity, face validity and construct validity were investigated. At the reliability stage; coefficient of internal consistence, $27 \%$ subgroup supergroup averages were measured and relationships between factors and $27 \%$ subgroup supergroup relationships were of scale items were examined. At the end of the research a scale, whose validity and reliability were validated, with 3 subgroup and 18 items aimed at 'The definition of ideas of3rd and 4th grade primary school student about child rights' developed.

\section{Giriş}

Çocuklar saf, hassas, istekli ve ilerlemekte olan bir insan topluluğudur; aynı zamanda da kaygılı ve ümitlidir. Bu dönemi hareket ederek, kendini olgunlaştırarak ve bilgi sahibi olarak geliştirirse donanımlı olur. Gelecekte de insanların kendini geliştirmelerine destek olur. Bu yüzden devletler ileri gitme, sulh, bolluk ve rahatlik ortamında devam etmeyi arzuluyorlarsa çocukların güvenli gelişmelerine ve becerileri yönünde ilerlemelerine özen göstermek zorundadır. Çocukların güvenliği, kendisini "bir varlık" olarak hissettirerek, huzur ve sevgi anlayışına uygun

\footnotetext{
*Bu makale ikinci yazarın, 2018 yılında Kaya Tuncer Çağlayan danışmanlığında Ondokuz Mayıs Üniversitesi, Eğitim Bilimleri Enstitüsü, İlköğretim Anabilim Dalı'nda yürüttüğ̈̈ "İlkokul 3. ve 4. Sınıf Öğrencilerinin Çocuk Hakları Konusundaki Bilinç Düzeylerinin Belirlenmesi: Bir Ölçek Geliştirme Çalışması" başlıklı doktora tezinden üretilmiştir.

** Sorumlu yazar/Corresponding author

e-posta: mehmet.akgul@gop.edu.tr
} 
bir biçimde sağlanır. Böylece çocuk, toplumun bir parçası olduğu düşüncesini benimseyerek büyür (İnan, 1968). Bir toplumun gelişmiş kültür seviyesine ulaşmış olduğunu gösteren en önemli göstergelerden birisi çocukları önemsemeleri ve onlara sağlıklı büyüme imkânları sunabilmeleridir (Akgül, 2015). Çağdaş uygarlıklar seviyesine ulaşmış bir topluluğun son derece önemli bir öğesi olan çocuğun bedeni büyürken, zihni olgunlaşırken, davranışları ilerleyip toplumsallaşırken eğitimsel tedbirler gelişimine uygun olarak alınır ve uygulanır. Çocuk büyüyüp gelişirken kişi, aile ve topluluk ortamındaki makamını oluşturan hukuk kaidelerine de ihtiyacı vardır. İhtiyaçları giderilmemiş, hakkından mahrum kalmış çocuk, bilinçsizce yetiştirilmesinden ötürü ebeveynlerin, öğretmenin, çalıştıranın, zabıtanın, savcının ve hâkimin her şekilde baskı oluşturabileceği bir varlık olacaktır ve böyle bir varlığın sağlıklı gelişimi mümkün olmayacaktır. Çocuk hukuku bu sebepten önemlidir (Serozan, 2005). Çocuk hukuku yeni bir bilim koludur. Hukuk sadece güçlülerin haklarını koruyup kollayan kurallar bütünü olmaktan çok; güçsüzlerin, güven ortamında olmayan kişilerin menfaatiyle de alakadardır. $\mathrm{Bu}$ sebeplerden ötürü çocuk hukukunu düzenleme gereği doğmuştur. Hukuk, topluluğun yaşamını inceleyen ve uygulanması kamu kuvvetiyle desteklenen kaidelerin tümüdür. Çocuk hukuku ise, hukukun çocuklara has, farklı söyleyişle çocuk haklarını inceleyen bir koldur (İnan, 1968). Çocukların bedensel, bilişsel gelişimini, hayal dünyasını ve yaratıcılığını olumlu olarak gelişmesini sağlayıp destek olan asıl toplum ailedir. Farklı toplumsal ve hukuksal oluşum, ailede yaşandığı takdirde direk ve gerçek tabanda yer almaz. Bu sebepledir ki çocuğun büyütülmesi ve güvenliği tarihin önceki devirlerinden şimdiye dek ebeveynlerin ahlaki sorumluluğu olarak kabul görülmüştür. Ebeveynler ve çocuklar ortasındaki bağ Medeni Kanunlarda hususi hukuk tablosu içerisinde incelenmiştir. Bu sebeple çocuk hukuku yetersiz cümlelerle ebeveynler ve çocuklar arasındaki hakla, vazifeleri ve bağları inceleyen nedenlerden ortaya çıkar (Akgül, 2015). Çocuk ebeveynlerden görevleri yerine getirmesini nasil arzulayacaktır? Burada devletin çocuklara göre sorumlulukları başlamaktadır. Çocuklara, hukuk kaideleri ile ebeveynlere yönelik haklar ayırt etmiş devletin, çocukların güvenliği sağlaması mecburidir. Fakat, modern devletin çocuğa yönelik vazifesi; bedeni, hissi, zihinsel ve ahlaki emniyetine, diğer bir söyleyişle "güçlü yarınına" ilgi göstermeleri açısından sadece ebeveynleri kontrol etmesi yeterli değildir. Devlet benzer şekilde çocukların becerilerini, yaratıcılıklarını, gelişimlerini güvence altına alarak, onları topluma kazandırmak zorundadır. $\mathrm{Bu}$ durumda çocuk hukukunun mevzusuna, evladın ebeveynlerine yönelik hakları inceleyen kuralların yanında, çocuğun topluluk ve devlete yönelik haklarını inceleyen kurallar da yer alır (Akyüz, 2013). İnsan payları mevkiler hukukunun mühim mevzularından birisi olmuştur. Böylelikle bir insan olarak çocuk, milletlerarası düzgülerin güvenliğinden faydalanma imkânına ulaşmıştır. O halde en kapsamlı manasıyla çocuk hukuku, hususi hukuk, halk hukuku, toplumsal hukuk ve milletler hukukunun birleşerek oluşturdukları çocukların haklarını inceleyen kuralların tümünden oluşmaktadır. Kısaca çocuk hukuku, hukukun çocuklara has şubesidir. Çocuk hukuku, bu kaideleri izah eder, değerlendirir, açıkları gidermeye yönelik tavsiyeler verir ve geri kalan taraflarına ilişkin değerlendirmelerde bulunur. $\mathrm{Bu}$ kurallarla çocuk; saygınlığı, hürriyeti, orijinalliği ve gelișim ihtiyacı dikkat edilerek hususi şekilde korunur. Böyle kuralların fonksiyonları, çocuğun kuvvetsizliği ve büyüme ihtiyacı göz önünde bulundurularak, onları anne ve babasından, mektep, çalışma alanında, eğlence alanlarında, cadde, yargıevi, ıslahhane ve hapishanede... Kisacası toplulukta esirgeyip korumaktır (İnan, 1968). Hukuk ve hak arasında yakın bir bağlantı vardır. Hak, en kolay deyimiyle bir şeyi gerçekleştirme veya başkalarından bir şeyi gerçekleştirmelerini, belirli bir biçimde davranmalarını isteme durumudur. Bu hakkı güven himayesi altına alan ise hukuktur (Gözler, 2011).Yürürlükteki hukuk alanında çocuk hakları ise, çocuk hukukuyla ilgili yasalar tarafından düzenlenmiş, yargı sistemleriyle gerçekleştirilen koruma şekilleriyle birleştirilmiş hakları kapsar. Bu haklar, çocuğun bedensel, zihinsel, duygusal, sosyal, ahlâkî ve ekonomik bakımlardan koruma altına alınması ve gelişmesi şeklindedir. Bu durum çocuk hakları, çocuğun bedensel, zihinsel, duygusal, sosyal ve ahlâkî bakımlardan özgürlük ve saygınlık içinde, sağlıklı ve beklenen seviyede gelişebilmesi için hukuksal şartlar ile güvence altına alınan faydalardır. Çocuk haklarına değer veren hukuk kuralları, çocuğun önemini belirtmenin araçlarıdır. Bu haklar ve bunları güvence altına alan yasalar aracılığıyla çocuk, güçsüzlüğü ve özel ihtiyaçları önemsenerek korunur ve kollanır. Bu sayede insan hayatının en iyi ancak en duygusal dönemini kapsayan çocukluk dönemi uygun biçimde yaşama ve gelişme olanağına kavuşur (Akgül, 2015). Bu nitelik, çocukların vücut, his, ussal ve geleceğe emin adımlarla ilerlemeleri açısından himayesinin birinci evleviyeti taşıması manasına gelir. 1990 yılında New York'ta toplanan 'Dünya Çocuk Zirvesi", tüm memleketlere "çocuklara birinci öncelik" prensibini rehber edinmeleri davetinde bulunmuştur. Bahsedilen prensip çocukların asıl ihtiyaçlarının iyi günde, zor günde gerek milli ve milletlerarası seviyelerde gerekse aile dâhilinde mevcut kaynakların ayrılması sırasında yukarı seviyeye taşıması gerekliliğini ifade etmektedir. Büyüyüp gelişmek için çocuğun elinde tek bir olanak vardır. Ayrıca, bu büyüme ve gelişme süreci oldukça duyarlı ve nazik bir nitelik arz eder. Bu sebeple "birinci öncelik ilkesi', gereğince, çocuğun faydaları daima her şartta öncelikle himaye edilmelidir (Serozan, 2005). Çocuk anayasasında bulunan bağları denetleyen hukuk düzenlemeleri, genellikle hükmedici şartlardır. Diğer bir söyleyişle şahıslar bu içerikte yasalarda derlenmiş olan münasebetlerin içeriğini ve boyutunun aksini yapamaz. Örneğin, velilik ve vasilik hükümetin gözetimi doğrultusunda elde edilir. Yasalar, ebeveyn ve çocuklarının çocuk haklarına kendi kendine dâhil olma sorumluluğu vermiştir. İster hususi tüzük isterse yasa tüzüğü olsun, çocuk tüzüğünün yerine kabul edilen şartlar derlenirken halk tüzüğünün devlet faydası, devlet nizamı ve güçsüzlere sahip çıkılması gibi prensiplerin büyük katkısı olmuştur. Bununla birlikte, hukukun başlıca prensiplerinden olan toplumsal hükümet öğesi, bu durumdaki kanun şartlarının fikir beyan etme ve sunulmasında yaygın etkisi vardır (Akyüz, 2013). Çocuk hukukunda kuralların derlenmesinde anlaşma serbestisine yer ayrılmıştır. Ebeveyn ve çocuklar arasındaki uyumun hangi yöntem ile ve hangi şartlarda sağlanacağı belirtilmiştir. Çocuklar gelişi güzel nüfusa alınamazlar, ebeveynlerin yetkisi ile çocukluktan men edilemezler. Evladın birden çok soy bağı olamaz, mahkeme kararı olmadan da soy bağından men edilemez. Bununla birlikte taraflar Anayasa'da belirtilmiş olan bağlantıların 
konusunu ve büyüklüğünü değiştiremezler. Örneğin, ebeveynler kanunu kendileri değiştirerek ebeveynlerden birinin veli olmasına hükmedemezler. Çocuğu belirli olgunluktan önce çalıştırılamazlar. Çocuk hukuku düzlemindeki hemen hemen tüm prosedürler noterler veya hâkimler vasıtasıyla belirlenir. Zayıfların güvenliği şimdiki anayasada önemli bir yere sahiptir. Çocuklar zayıfların gruplandırılması mevzuunda özel görüşleri ayarlamada yardımcıdırlar. Hukukun "toplumsal mevki" prensibi içinde içten ve doğal kuvvetsizliği olan çocuklar, zayıfların korunması konusuna göre, ebeveynleri ile birlikte imkânına sahip olarak topluluk ortamında güven altına alınması konusunda önceliğe sahiptirler (Akyüz, 2000). Genel olarak insan hakları, demokrasi kültürü ve çocuk hakları konularında sağlanan ilerlemeler günümüzde gelişmiş ülkeler arasında yer almanın temel göstergeleridir. Türkiye'de bu alanda kısa dönemde ilerlemelerin sağlanması için zihniyet değişikliğine, yapısal değişikliğe ve uygulama değişikliğine gereksinme vardır. Tüm alanda yapılacak çalışmaların niteliği, bu değişikliklerin sağlanmasına bağlıdır. İnsan hakları ve çocuk hakları ile ilgili tüm tarafların bilgilenme ve eğitim görme hakları vardır. Öğrenmeye açık bir toplum olarak, öğrenen kurumların ve öğrenen bireylerin aktiviteleri, demokrasi ve insan hakları kültürün geliştirilmesine önderlik edecektir. Gün 1şı̆̆ımız, aydınlığımız olan çocuklarımızın yetiştirilmesinde sorumluluk alanların rolleri, gönümüzde büyük bir önem teşkil etmektedir. Onların liderliğinde ve çocukların katılımıyla gerçekleşecek demokrasi ve insan haklarını öğrenme ve uygulama ortamları, gelişmenin filizlendiği çağdaş ortamlar olacaktır (C1lga, 2001). Gelişmekte olan Türkiye'de çocukların ve gençlerin yaşam koşullarının iyileştirilmesi ve yaşam niteliklerinin yükseltilmesi için toplumsal birikimin önemini kavrayarak ulusal ve uluslararası iş birliğine girilmesi bilinçli çabalara yol gösterecektir. Türkiye'de çocuğun hak ve çıkarlarını gözeten, yaşama, bakılma, korunma, yetişme, gelişme ve katılma haklarını eşitlikçi bir anlayışla geliştiren, çocuğun varlık olarak değerini yücelten, düşünce, istek ve eğilimlerine saygı gösteren bir çocuk hukuku düzeninin oluşturulması ve uygulanması temel gereksinmedir (Cılga, 2001).Çocuğun korumasız olması, bu durumun herkes tarafindan bilinmesi ve bazı kesimlerce çocuğun toplumda birey olarak kabul görmemesi çocuk haklarının ne kadar önemli olduğunu ve araştırılması gerektiğini vurgular niteliktedir. "Çocuk Hakları" kesinlikten yoksundur ve "tanım peşinde bir slogan” olarak betimlenir. Çocuk hakları meselesi kuşkusuz karmaşıktır ve toplumsal soruların yanı sıra felsefi, ahlaki ve yasal sorular da getirir (Rodham, 1973). Çocuklara ve dolayısıyla insanın saygınlığına yönelik talepler arasına kişisel dokunulmazlık, özerklik, etiketlenmeme özgürlüğü ve insan 1rkının herhangi bir meşru üyesine gösterilen saygıyı görme haklarını belirtmek mümkündür.Şu anda çocuklar, yetişkinlerin tam, özgür bir yaşam için vazgeçilmez gördükleri haklardan yoksunlar. Çocuk haklarının son kategorisi çocukların var olan reşitlik yaşına ulaşmadan önce ana babaları karşısında daha fazla bağımsızlığa sahip olmaları gerektiğini ileri sürer. Çocukların ilgi ve koruma gerektiren özel ihtiyaçları vardır ve çocuklar olarak ihtiyaçlarını karşılamak üzere özel olarak hazırlanmış hakları olması ve bu hakların çocukların kendisi ve herkes tarafindan bilinip uygulanması gerekir (Franklin, 1993). Çocukları her türlü ihmal ve istismardan kurtarmak, yasal ve toplumsal açıdan korunmalarını ve geleceğe hazırlanmalarını sağlamak hem toplum kalkınması hem de insan hakları açısından son derece önemlidir. Sorunları çözmenin ilk adımı ise bu çocukları ve sorunlarını bütünüyle tanımaktır (Şişman, 2006). Çocuk hakları konusuna olan ilgi ve verilen önem son yillarda oldukça artmıştır. Fakat çocuk haklarını çocukların ve genel olarak toplumun ne kadar bildiği, özen gösterdiği ve uyguladığına yönelik çalışmalar oldukça azdır.Çocuk hakları sözleşmesinde yaşama, gelişme, korunma, bakım ve katılım hakları çerçevesi altında çocukların sahip olduğu haklar belirtilmiştir. Her çocuğun kendi hakkını bilmesi, koruması ve diğer çocukları da bilgilendirmesi ve onları gözetmesi açısından haklarının neler olduğunu bilmesi oldukça önemlidir. $\mathrm{Bu}$ sebeple çocukların çocuk hakları konusundaki bilinç düzeylerini belirleyen geçerli ve güvenilir ölçeklerin varlığı ve bu ölçekler vasıtasıyla çocukların çocuk hakları konusundaki bilinç düzeylerinin belirlenmesi, onların sağlıklı birer yetişkin bireyler olmaları konusunda oldukça etkilidir.

\subsection{Araştırmanın Problemi}

Araştırma problemi şu şekilde belirlenmiştir:

İlkokul 3. ve 4. sınıf öğrencilerinin çocuk hakları konusundaki bilinç düzeylerini ölçmeye yönelik geliştirilen ölçek geçerli ve güvenilir midir?

Belirlenen temel problem doğrultusunda araştırılan alt problemler aşağıdaki gibidir:

1. İlkokul 3. ve 4. sınıf öğrencilerinin çocuk hakları konusundaki bilinç düzeylerini ölçmeye yönelik geliştirilen ölçeğin kapsam geçerliliği sağlanmış mıdır?

2. İlkokul 3. ve 4. sınıf öğrencilerinin çocuk hakları konusundaki bilinç düzeylerini ölçmeye yönelik geliştirilen ölçeğin yapı geçerliliği sağlanmış mıdır?

$\mathrm{Bu}$ alt probleme yönelik aşağıdaki sorulara yanıt aranmıştır:

2.1. Geliştirilen ölçeğin yapı geçerliliği kapsamında açımlayıcı faktör analizi sonuçları literatürde kabul edilebilir değerler arasında mıdır?

2.2. Geliştirilen ölçeğin yapı geçerliliği kapsamında doğrulayıcı faktör analizi sonuçları literatürde kabul edilebilir değerler arasında mıdır?

\subsection{Araştırmanın Amacı}

Çocukların "çocuk hakları” konusundaki bilinç düzeylerini belirlemeye yönelik geçerli ve güvenilir bir ölçek geliştirilmesi, ilkokul öğrencilerinin çocuk hakları konusundaki bilinç düzeylerini ölçmeye yönelik ölçek sayısının oldukça sınırlı olması ve bilinç düzeylerinin ölçmesi bakımından farklı bir örnek teşkil edeceği düşünülmektedir. Ülkemizde ve yurtdışında yapılan araştırmalar incelendiğinde ilkokul 3 . ve 4 . sınıf öğrencilerinin çocuk hakları konusundaki bilinç düzeylerini belirlemeye yönelik ölçek geliştirme çalışmalarının ve bilinç düzeyi belirleme çalışmalarının oldukça az olduğu görülmüştür. Yine ilkokul 3. ve 4. sınıf öğrencilerinin çocuk hakları konusundaki bilinç düzeylerini belirlemeye yönelik ölçek geliştirmeyi konu alan araştırmalar incelendiğinde, "okulda, evde ve öğrenci için önemi" şeklinde farklı alanlarda bilinç düzeyini belirlemeye yönelik çalışmaların ülkemizde bulunmadığı, yurtdışında 
ise oldukça az olduğu görülmektedir. Yapılan incelemeler sonrasında bu araștırmanın genel amacı ilkokul 3. ve 4. sınıf öğrencilerinin çocuk hakları konusundaki bilinç düzeylerini belirlemeye yönelik geçerli ve güvenilir bir ölçek geliştirmek ve bilinç düzeylerini belirlemektir.

\section{Yöntem}

\subsection{Araştırma Modeli}

$\mathrm{Bu}$ araştırma bir ölçek geliştirme çalışması olup, ölçek kavramı temelinde ölçme sonuçlarını göstermenin yanısıra sosyal bilimlerinin birçok alanında; hedeflenen kişiler, sistem, konu ya da içerik açısından bilgi elde etmek amacıyla kullanılmaktadır (Yurdugül, 2005).

\subsection{Evren ve Örneklem}

Çalışmanın amacına ve araştırma desenine uygun olarak araştırmanın evrenini 2017-2018 ve 2018-2019 eğitim öğretim yıllarında eğitim öğretim gören 3 . ve 4 . sınıf öğrencileri oluşturmaktadır. Araştırmanın örneklemini ise random (rastgele) örnekleme yöntemi ile ulaşılan 2017 2018 ve 2018-2019 eğitim öğretim yılında Tokat il genelinde 3. ve 4. sinıflarda öğrenim gören 501 ilkokul öğrencisi oluşturmaktadır.

\subsection{Veri Toplama Arac1}

Araştırmada veri toplama aracı olarak bu çalışmada araştırmacı tarafından geliştirilmiş olan "Çocuk Hakları Bilinç Düzeyi Belirleme Ölçeği" kullanılmıştır. Ölçek son haliyle "Korunma Hakkı", "Özgür Yaşama Hakkı" ve "Bilgi Edinme ve Görüş Bildirme Hakkı" olmak üzere 3 boyut ve 18 maddeden oluşmaktadır. Ölçek Evde, okulda, sizin için önemi olmak üzere 3 kategoride geliştirilmiş olup; kategoriler kendi arasında 3'lü likert tipinde hazırlanmış, (0-1-2) olarak puanlandırılmıştır. Ölçek geliştirmede analiz aşamalarında geçici olarak ölçeğin 3 kategorisi tek kategoriye indirilip 7'li likert tarzına çevrilmiştir. Ölçek geliştirme analiz aşamalarından sonra tekrarda eski haline çevrilmiştir. Katılımcının ölçekten alabileceği en yüksek puan 108 iken, en düşük puan 0'dır. Puanlar yükseldikçe öğrencinin çocuk hakları konusundaki bilinç düzeyi yüksek olduğu anlamına gelmektedir. Ölçeğin geliştirilmesine yönelik detaylı bilgilere bulgular kısmında yer verilmiştir.

\subsection{Verilerin Analizi}

Verilerin analizinde SPSS 20 ve Lisrel programları kullanılmıştır. $\mathrm{Bu}$ araştırma bir ölçek geliştirme çalışması olup, ölçek kavramı temelinde ölçme sonuçlarını göstermenin yanısıra sosyal bilimlerinin birçok alanında; hedeflenen kişiler, sistem, konu ya da içerik açısından bilgi elde etmek amacıyla kullanılmaktadır (Yurdugül, 2005). Bu çalışma sürecinde literatür ya da uzman görüşleri doğrultusunda taslak ölçek formu elde edilmiş ve sonrasında ise örneklem grubuna deneme uygulaması yapılmıştır. Ön uygulama sırasında taslak ölçek formunda eksik görülen ya da öğrencilerin anlamakta güçlük çektiği kısımlar düzeltilmiş ve nihai form elde edilmiştir. Nicel bir çalışma özelliği taşıması açısından, açımlayıcı ve doğrulayıcı faktör analizlerinin yapılması ve çalışmanın büyük örneklem gerektirmesi bu sürecin karakteristik özelliklerindendir.

\section{Bulgular ve Yorumlar}

Bu bölümde ölçeğin geliştirilmesi sırasında yapılan geçerlik ve güvenirlik çalışmaları açıklanmıştır. $\mathrm{Bu}$ sebeple açımlayıcı faktör analizi (AFA), doğrulayıcı faktör analizi (DFA), iç tutarlılık güvenirlik katsayıları (Cronbach alfa) sonuçlarına yer verilmiştir.

\subsection{Birinci Alt Probleme İlişkin Bulgular}

Kapsam geçerliliğini test etmede kullanılan mantıksal yollardan biri, uzman görüşüne başvurmaktır (Büyüköztürk, 2008). Bu amaçla yapılan çalışmada, toplam 101 maddeden oluşan madde havuzu, alanında uzman 15 akademisyenden ve sınıf öğretmeninden görüş alınarak tekrar değerlendirilmiş, uygun görülmeyen (yönlendirici olduğu düşünülen, çocukların seviyesinin üstünde olduğu düşünülen, tekrara düşülen) sorular çıkarılmış, gerekli düzeltmeler yapılmış ve 88 maddelik ön deneme ölçeği hazır hale getirilmiştir. Ölçek çocukların çocuk hakları konusundaki bilinç düzeylerini belirlemeye yönelik bir ölçme aracı olarak tasarlandığından, maddelerin 0 (HayırKatılmıyorum), 1 (Kararsızım), 2 (Evet-Katılıyorum) şeklinde üçlü likert ve üç farklı alanda (okulda, evde, sizin için önemi) tipinde puanlanmasına karar verilmiştir.

\section{2. İkinci Alt Probleme İlişkin Bulgular}

Yapı geçerliliğini incelemek amacıyla faktör analizi, iç tutarlık analizi ve hipotez testi gibi istatistiki analiz yöntemleri kullanılmaktadır (Büyüköztürk, 2008). Bu çalışma kapsamında yapı geçerliğini saptamak amacı ile AFA ve DFA yapılmıştır. Analize geçmeden önce AFA ve DFA yapılabilmesi için (okulda, evde, sizin için önemi) alanlarının toplam puanlarını alıp ölçek 7'li likert tipine dönüştürülmüş ve analizler bu şekilde yapılmıştır. Analizler bittikten sonra ölçek tekrar 3'lü likert tipine çevrilmiştir. Faktör Analizi, aynı yapıyı ölçen değişkenleri bir araya getirerek ölçmeyi az sayıda faktörle açıklamayı amaçlar. Araştırmada, faktörleştirme tekniği olarak Temel Bileşenler Analizi kullanılmıştır. Temel Bileşenler Analizi, değişken azaltmayı ve anlamlı kavramsal yapılara ulaşmayı amaçlayan, yorumlaması göreceli olarak kolay olduğu için de uygulamalarda siklıkla kullanılan bir tekniktir (Büyüköztürk, 2013). Faktör analizine uygunluğunun incelenmesi için KMO (Kaiser-Meyer-Olkin) katsayısı ve Bartlett Küresellik Testi sonuçlarına bakılmıştır. KMO değeri 0-1 arasında değişmektedir ve bir ölçeğin faktör analizine uygun olarak kabul edilmesi için KMO katsayısının 0,50 değerinden daha büyük ve Bartlett testinin anlamlı çıkması gerekmektedir. KMO değerinin .50-.60 arasında olması 'kötü', .61-.70 arasında olması 'zayıf', .71.80 arasında olması 'orta', .81-.90 arasında olması 'iyi' ve .90 üzerinde olması 'mükemmel' olduğunu ortaya koymaktadır (Şencan, 2005; Çokluk, Şekercioğlu ve Büyüköztürk, 2014). 
Tablo 1. Kaiser-Meyer-Olkin Katsayısı ve Bartlett Testi Sonuçları

\begin{tabular}{lll}
\hline KMO KatsayıSI & &, 862 \\
\hline & $\mathbf{X}^{2}$ & 11616,014 \\
Bartlett Testi & Sd & 3828 \\
& P &, 000 \\
\hline
\end{tabular}

Tablo 1'deki veriler incelendiğinde KMO katsayısının 0,862 olduğu ve Bartlett Testi'nin de anlamlı düzeyde $(\mathrm{p}<.05) \quad$ çıktığı görülmektedir. $\mathrm{Bu}$ verilere dayanarak taslak ölçeğin faktör analizine uygun olduğu anlaşılmaktadır. Uygulama sonucunda elde edilen verilerin ölçülmek istenen özelliklerle ilgili temel faktörlerin belirlenmesi amacıyla açımlayıcı faktör analizi yapılmıştır. Temel faktörlerin belirlenmesi amaciyla Temel Bileşenler Analizi (Principle Component Analysis) ve faktörleri yorumlamak, açıklık ve anlamlılığını sağlamak için de Varimax döndürme tekniği kullanılmıştır.

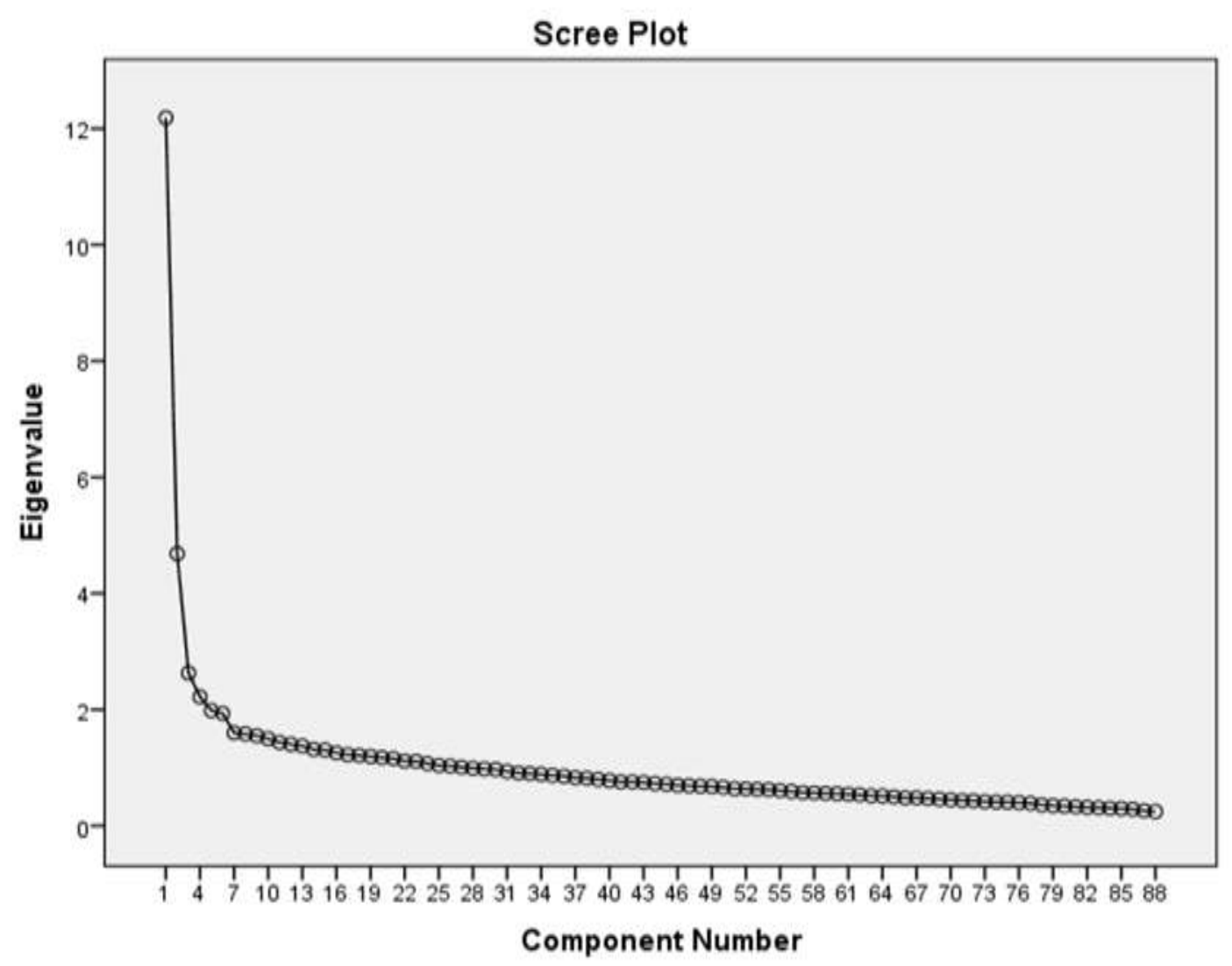

Şekil 1. Taslak Ölçeğin Yamaç Birikinti Grafiği (Scree Plot)

Yamaç Birikinti Grafiği incelendiğinde grafiğin düzleşmeye başladığı kısımlar, değerlerin birbirine yakınlığı ve toplam varyans değeri tablosu da dikkate alınarak ölçeğin faktör sayısının 5 olmasına karar verilmiştir. Açımlayıcı faktör analizi için temel bileşenler analizi Varimax dik döndürme kullanılmıştır.
Genel olarak, faktöryük değerleri .30 ve daha yüksek olan maddelerin bireyleri iyi derecede ayırt ettiği, .40 ve üzerinde ise maddelerin çok iyi olduğu kabul edilmektedir (Büyüköztürk, 2002; Büyüköztürk, Çakmak, Akgün, Karadeniz ve Demirel, 2008). Bu nedenle ilk döndürmede .40'ın altında kalan ve birden fazla faktörde yüklenen maddeler çıkarılmıştır.

Tablo 2. Döndürülmüş Bileşenler Matrisi

\begin{tabular}{|c|c|c|c|c|c|}
\hline \multicolumn{6}{|l|}{ Faktörler } \\
\hline & 1 & 2 & 3 & 4 & 5 \\
\hline m51 & ,695 & & & & \\
\hline m52 & 649 & & & & \\
\hline m54 & 637 & & & & \\
\hline m53 & ,624 & & & & \\
\hline m60 & ,567 & & & & \\
\hline $\mathrm{m} 87$ & 561 & & & & \\
\hline $\mathrm{m} 83$ & ,546 & & & & \\
\hline
\end{tabular}




\begin{tabular}{ll}
\hline m46 &, 545 \\
m57 &, 542 \\
m66 &, 534 \\
m16 &, 522
\end{tabular}

m79 ,686

$\mathrm{m} 78$

m65, 615

m76, 507

$\mathrm{m} 74$

$\mathrm{m} 8 \quad, 450$

m32 ,409

$\mathrm{m} 13 \quad, 750$

$\mathrm{m} 12+\frac{715}{72}$

$\mathrm{m} 2 \quad, 630$

$\mathrm{m} 18 \quad, 720$

$\mathrm{m} 20 \quad$,626

$\mathrm{m} 17 \quad$,608

$\mathrm{m} 10 \quad, 524$

$\mathrm{m} 27$

m30 $\quad, 729$

m61 588

Maddelerin faktör yük değerlerine bakılmış ve faktör analizinde aynı yapıyı ölçmeyen maddelerin ayıklanması için maddelerin faktör yüklerinin 0.40 ya da daha yüksek olmasına, bir maddenin faktörlerdeki en yüksek yük değeri ile bu değerden sonraki en yüksek yük değeri arasındaki farkın en az 0.10 olmasına ve ortak faktör varyansına dikkat edilmiştir. $\mathrm{Bu}$ değerlere uyularak varimax döndürme sonucu oluşan tabloda aralarında 0.10 'dan daha az fark olan maddeler binişik maddeler olarak kabul edilmiş ve her madde atılmasında tekrar döndürme işlemi yapılarak binişik maddeler ölçekten atılmıştır. Nihai olarak faktör yük değeri 0.40 'ın altında olan madde kalmamıştır.

Tablo 3.Ölçeğin Nihai Madde-Toplam Korelasyonları ve Madde Atıldığındaki Cronbach Alpha Değerleri

\begin{tabular}{|c|c|c|}
\hline & Madde-Toplam Korelasyonu & $\begin{array}{c}\text { Madde Atıldığında } \\
\text { Cronbach Alpha }\end{array}$ \\
\hline $\mathrm{m} 51$ & ,501 &, 840 \\
\hline $\mathrm{m} 52$ & ,481 & 840 \\
\hline m53 & ,437 & ,841 \\
\hline m54 & ,445 & ,841 \\
\hline m60 &, 503 & ,838 \\
\hline $\mathrm{m} 87$ &, 523 & ,838 \\
\hline $\mathrm{m} 83$ & ,469 & 840 \\
\hline $\mathrm{m} 46$ & ,492 &, 839 \\
\hline m57 & ,493 & ,839 \\
\hline m66 & ,398 &, 842 \\
\hline $\mathrm{m} 16$ & ,369 &, 844 \\
\hline $\mathrm{m} 79$ &, 354 &, 846 \\
\hline $\mathrm{m} 78$ &, 537 & ,837 \\
\hline m65 & ,369 &, 845 \\
\hline $\mathrm{m} 76$ & 344 &, 845 \\
\hline $\mathrm{m} 74$ & ,471 &, 839 \\
\hline $\mathrm{m} 32$ & ,434 &, 841 \\
\hline $\mathrm{m} 8$ & ,310 &, 847 \\
\hline $\mathrm{m} 12$ & ,308 &, 847 \\
\hline $\mathrm{m} 13$ & ,406 &, 842 \\
\hline $\mathrm{m} 2$ & ,385 &, 843 \\
\hline $\begin{array}{l}\text { Madde toplam } \\
\text { maddeler tekeı } \\
\text { işleminden } \mathrm{s}\end{array}$ & $\begin{array}{l}\text { n korelasyon değeri .30'un altında olan } \\
\text { ar teker atılmış ve her madde çıkarma } \\
\text { sonra madde toplam korelasyonları }\end{array}$ & $\begin{array}{l}\text { hesaplanmıştır. Sorunlu } \text { olarak görülen maddeler } \\
\text { çıkarıldıktan sonra madde toplam korelasyonları tekrar } \\
\text { hesaplanmış ve değerlerin } .308 \text { ile } .537 \text { arasında değiştiği } \\
\text { belirlenmiştir. }\end{array}$ \\
\hline
\end{tabular}

Tablo 4.Ölçekteki Maddelerin Nihai Ortak Faktör Varyans Değerleri (communalities)

\begin{tabular}{|c|c|c|}
\hline & Initial & Extraction \\
\hline$\overline{\mathrm{m} 51}$ & 1,000 &, 500 \\
\hline m52 & 1,000 & ,417 \\
\hline m53 & 1,000 & ,448 \\
\hline m54 & 1,000 & 420 \\
\hline m60 & 1,000 & 380 \\
\hline m87 & 1,000 & ,413 \\
\hline $\mathrm{m} 83$ & 1,000 & ,344 \\
\hline $\mathrm{m} 46$ & 1,000 & 379 \\
\hline
\end{tabular}




\begin{tabular}{|c|c|c|}
\hline m57 & 1,000 & ,378 \\
\hline $\mathrm{m} 16$ & 1,000 & ,354 \\
\hline m79 & 1,000 & ,559 \\
\hline $\mathrm{m} 78$ & 1,000 & ,561 \\
\hline $\mathrm{m} 76$ & 1,000 & ,335 \\
\hline $\mathrm{m} 65$ & 1,000 & ,436 \\
\hline $\mathrm{m} 74$ & 1,000 & ,367 \\
\hline $\mathrm{m} 2$ & 1,000 & ,484 \\
\hline $\mathrm{m} 12$ & 1,000 & ,580 \\
\hline $\mathrm{m} 13$ & 1,000 & ,615 \\
\hline
\end{tabular}

Maddelerin ortak faktör varyans değerlerine (communualities) bakılmış ve .30'un altında değer alan madde kalmamıştır.

Tablo 5.Ölçekteki Alt Boyutların Özdeğerleri ve Açıklanan Toplam Varyans Değerleri

\begin{tabular}{lcccccc}
\hline Component & Toplam & Özdeğer İstatistiği & \multicolumn{3}{c}{ Açılanan Toplam Varyans } \\
& \% Varyans & Kümülatif \% & Toplam & \% Varyans & Kümülatif \% \\
\hline 1 & 5,006 & 27,810 & 27,810 & 3,841 & 21,340 & 21,340 \\
2 & 1,625 & 9,028 & 36,837 & 2,267 & 12,595 & 33,935 \\
3 & 1,339 & 7,441 & 44,278 & 1,862 & 10,343 & 44,278 \\
\hline
\end{tabular}

Gerekli şartları sağlayamayan maddelerin ölçekten atılması $\quad$ varyansın \%40 ile \%60 arasında olması yeterli olarak kabul sonucu 3 faktörlü ve 18 maddeden oluşan ölçek ortaya edilir (Çokluk ve diğerleri, 2014). Faktörlerin özdeğerleri çıkmıştır. Ölçeğin toplam varyansı açıklama yüzdesi 44,278 incelendiğinde; birinci faktörün 5,006; ikinci faktörün olarak hesaplanmıştır. Çoklu faktörlü desenlerde, açıklanan $\quad 1,625$; üçüncü faktörün özdeğeri 1,339'dur.

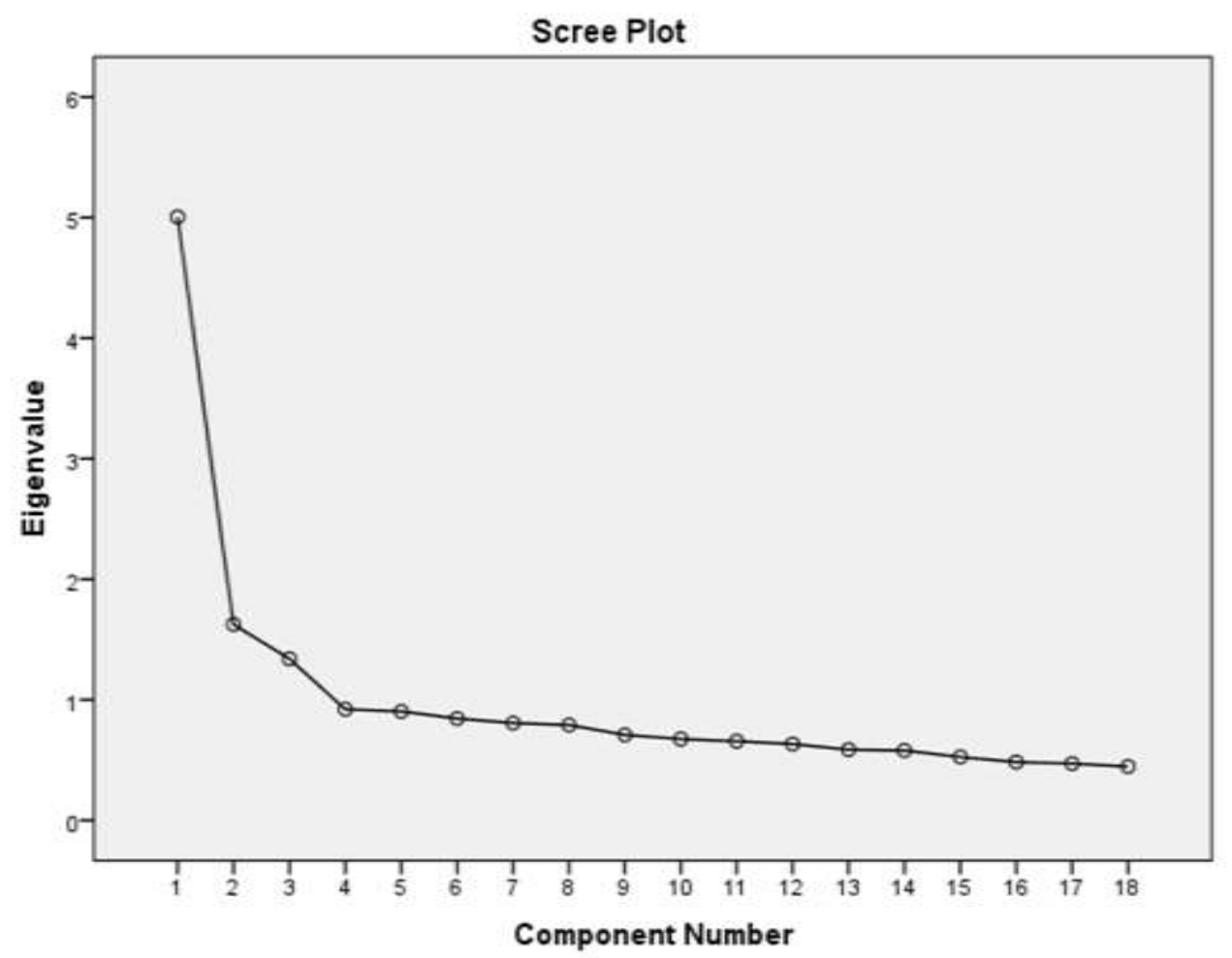

Şekil 2. Nihai Ölçeğin Yamaç Birikinti Grafiğgi (Scree Plot)

Yamaç Birikinti Grafiği tekrar incelendiğinde grafiğin düzleşmeye başladığı kısımlar, değerlerin birbirine yakınlığı ve toplam varyans değeri tablosu da dikkate

Tablo 6. Nihai Ölçek Maddelerinin Faktörlere Göre Dağılımları, Faktör Yükleri, Madde-Toplam Korelasyonları ve Açıklanana Varyans Değerleri

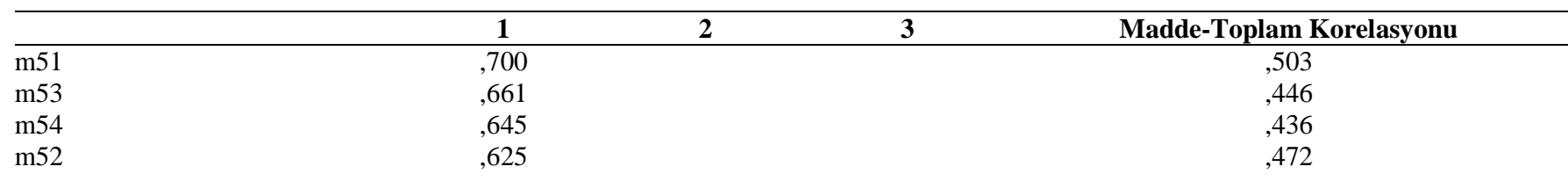




\begin{tabular}{|c|c|c|}
\hline m87 &, 576 & \\
\hline $\mathrm{m} 46$ & ,562 & \\
\hline $\mathrm{m} 60$ & 557, & \\
\hline m57 &, 556 & \\
\hline $\mathrm{m} 83$ & ,528 & \\
\hline m16 &, 524 & \\
\hline m79 & & ,716 \\
\hline $\mathrm{m} 78$ & & ,692 \\
\hline m65 & & ,651 \\
\hline $\mathrm{m} 76$ & &, 533 \\
\hline $\mathrm{m} 74$ & & ,508 \\
\hline $\mathrm{m} 13$ & & \\
\hline $\mathrm{m} 12$ & & \\
\hline $\mathrm{m} 2$ & & \\
\hline Açıklanan Varyans & 27,810 & 9,028 \\
\hline \multicolumn{3}{|c|}{$\begin{array}{l}\text { Faktörlerde bir araya gelen maddeler incelendiğinde } 1 \text {. faktör } \\
\text { "Korunma Hakk1" olarak isimlendirilmiş ve faktör yükü az } \\
\text { olandan fazla olana göre şöyle sıralanmıştır: } 16,83,57,60,46,87 \text {, } \\
52,54,53 \text { ve } 51 \text {. maddeler. Korunma Hakk1 alt boyutunun } \\
\text { varyans1 açıklama yüzdesi } 27,810 \text { 'tır. Faktör yükleri ise } 0.700- \\
0.524 \text { arasında değişmektedir. Ölçeğin } 2 \text {. faktörü "Özgür Yaşama } \\
\text { Hakkı" olarak isimlendirilmiş ve faktör yükü az olandan fazla }\end{array}$} \\
\hline
\end{tabular}

$\begin{array}{ll} & , 526 \\ & , 499 \\ & , 495 \\ & , 496 \\ & , 473 \\ & , 373 \\ & , 343 \\ & , 525 \\ & , 349 \\ , 758 & , 343 \\ , 748 & , 462 \\ , 645 & , 396 \\ , 7408 \\ 7,441\end{array}$

7,441

Toplam Varyans: 44,278

olana doğru maddeler $74,76,65,78$ ve 79 olarak sıralanmıştır. Özgür Yaşama Hakkı alt boyutunun varyansı açıklama yüzdesi 9,028'dir. Faktör yükleri ise 0.716-0.508 arasında değişmektedir. Ölçeğin 3. faktörü "Bilgi Edinme ve Görüş Bildirme Hakkı" olarak isimlendirilmiştir ve faktör yükü az olandan fazla olana doğru maddeler 2, 12 ve 13 olarak sıralanmıştır. Bilgi Edinme ve Görüş Bildirme Hakkı alt boyutunun varyansı açıklama yüzdesi ise 7,441'dir. Faktör yükleri 0.758 - 0.645 arasında değişmektedir.

Tablo 7. Ölçek Alt Boyutları Arasındaki Korelasyon Değerleri

\begin{tabular}{lccc}
\hline FAKTÖRLER & Faktör 1 & Faktör 2 & Faktör 3 \\
\hline Faktör 1 & & & \\
Faktör 2 & $.45^{* *}$ & & \\
Faktör 3 & $.36^{* *}$ & $.32^{* *}$ & $.67^{* *}$ \\
Toplam & $.88^{* *}$ &.$* *$ \\
\hline
\end{tabular}

$* * \mathrm{p}<.01$

$\mathrm{N}=501$

Faktörler arasındaki korelasyonlar incelendiğinde birinci faktör ile ikinci faktör arasında pozitif yönde ve düşük düzeyde anlamlı bir ilişki bulunmaktadır $(\mathrm{r}=.45 ; \mathrm{p}<.01)$. Birinci faktör ile üçüncü faktör arasında pozitif yönde ve düşük düzeyde anlamlı bir ilişsi bulunmaktadır $(\mathrm{r}=.36 ; \mathrm{p}<.01)$. İkinci faktör ile üçüncü faktör arasında pozitif yönde ve düşük düzeyde anlamlı bir ilişki bulunmaktadır $(\mathrm{r}=.32 ; \mathrm{p}<.01)$. Alt boyutların toplam ölçekle olan ilişkisi incelendiğinde birinci faktör ile pozitif yönde ve kuvvetli düzeyde $(\mathrm{r}=.88 ; \mathrm{p}<.01)$, ikinci faktör ile pozitif yönde ve kuvvetli düzeyde $(\mathrm{r}=.77 ; \mathrm{p}<.01)$, üçüncü faktör ile pozitif yönde ve orta düzeyde $(\mathrm{r}=.60 ; \mathrm{p}<.01)$ anlamlı bir ilişki bulunmaktadır. Alt boyutlar arasında en yüksek ilişki birinci ve ikinci faktör arasında, en düşük ilişki ise ikinci ve üçüncü faktör arasındadır. Ölçek ve faktörler arasındaki ilişkide ölçeğin tamamıyla en yüksek ilişkiye sahip olan alt boyut birinci faktör, en düşük ilişkiye sahip olan alt boyut ise üçüncü faktördür.

Tablo 8. Ölçek Alt Boyutlarının Alt ve Üst \%27'lik Gruplar Arasındaki Farkı İncelemeye Yönelik Mann Whitney U Testi Sonuçları

\begin{tabular}{|c|c|c|c|c|c|c|}
\hline \multirow[t]{2}{*}{ FAKTÖRLER } & \multicolumn{2}{|c|}{$\begin{array}{c}\text { ALT GRUP } \\
(\mathbf{N}=135)\end{array}$} & \multicolumn{2}{|c|}{$\begin{array}{c}\text { ÜST GRUP } \\
(\mathbf{N}=135)\end{array}$} & \multirow[b]{2}{*}{$\mathbf{Z}$} & \multirow[b]{2}{*}{ p } \\
\hline & S.O. & S.T. & S.O. & S.T. & & \\
\hline Faktör 1 & 68,57 & 9256,50 & 202,43 & 27328,50 & $-14,307$ & $.000^{* * * *}$ \\
\hline Faktör 2 & 69,82 & 9425,50 & 201,18 & 27159,50 & $-13,859$ & $.000^{* * *}$ \\
\hline Faktör 3 & 79,35 & 10712,50 & 191,65 & 25872,50 & $-11,937$ & $.000^{* * * *}$ \\
\hline Toplam & 68,00 & 9180,00 & 203,00 & 27405,00 & $-14,217$ & $.000^{* * * *}$ \\
\hline
\end{tabular}

$* * * \mathrm{p}<.001$

Ölçeğin alt boyutlarında alt ve üst \%27'lik gruplar arasındaki farkın bulunmasına yönelik hangi testin yapılacağına karar verilmeden önce grupların normal dağılıma sahip olup olmadığı incelenmiştir. Grupların normal dağılım göstermediği belirlenmiş ve parametrik olmayan testlerin uygulanmasına karar verilmiştir. Ölçeğin ayırt edicilik özelliklerinin belirlenebilmesi amaciyla \%27 alt $\operatorname{grup}(\mathrm{N}=135)$ ve \%27 üst grup $(\mathrm{N}=135)$ arasındaki ortalama puanları arasındaki farkın anlamlı olup olmadığını ortaya çıkarmak için bağımsız gruplar $\mathrm{t}$ testi yapılmıştır. Bu test sonucu alt boyutlarda ve ölçekte üst ve alt \%27'lik grupların puanları karşılaştırılmıştır. Ölçek ve alt boyutlardaki ayırt ediciliği belirlenebilmesi amacıyla $\% 27$ 'lik üst ve alt gruplar arasında yapılan bağımsız gruplar $\mathrm{t}$ testi sonuçları incelendiğinde ölçeğin tamamında ve alt boyutlarda anlamlı bir farklılı bulunmaktadır $(\mathrm{p}<.001)$. Buna göre ölçeğin tamamının ve alt boyutlarının ölçülmek istenen özelliği ölçmede ayırt edici olduğu söylenebilir.

Tablo 9. Ölçek Maddelerinin Alt ve Üst \%27'lik Gruplar Arasındaki Farkı İncelemeye Yönelik Mann Whitney U Testi Sonuçları

\begin{tabular}{|c|c|c|c|c|c|c|}
\hline \multirow[t]{2}{*}{ MADDELER } & \multicolumn{2}{|c|}{$\begin{array}{c}\text { ALT GRUP } \\
(\mathrm{N}=135)\end{array}$} & \multicolumn{2}{|c|}{$\begin{array}{c}\text { ÜST GRUP } \\
(\mathrm{N}=135)\end{array}$} & \multirow[b]{2}{*}{$\mathbf{Z}$} & \multirow[b]{2}{*}{$\mathbf{p}$} \\
\hline & S.O. & S.T. & S.O. & S.T. & & \\
\hline Madde2 & 95,33 & 12869,00 & 175,67 & 23716,00 & $-9,238$ &, 000 \\
\hline Madde12 & 91,30 & 12326,00 & 179,70 & 24259,00 & $-9,641$ &, 000 \\
\hline Madde13 & 91,83 & 12397,00 & 179,17 & 24188,00 & $-9,928$ &, 000 \\
\hline Madde16 & 98,19 & 13256,00 & 172,81 & 23329,00 & $-9,343$ &, 000 \\
\hline
\end{tabular}




\begin{tabular}{lcccccc}
\hline Madde46 & 89,17 & 12038,50 & 181,83 & 24546,50 & $-11,097$ &, 000 \\
Madde51 & 95,50 & 12892,50 & 175,50 & 23692,50 & $-10,440$ &, 000 \\
Madde52 & 88,13 & 11898,00 & 182,87 & 24687,00 & $-11,408$ &, 000 \\
Madde53 & 92,71 & 12516,00 & 178,29 & 24069,00 & $-10,188$ &, 000 \\
Madde54 & 102,80 & 13877,50 & 168,20 & 22707,50 & $-8,809$ &, 000 \\
Madde57 & 86,50 & 11677,00 & 184,50 & 24908,00 & $-11,586$ &, 000 \\
Madde60 & 84,02 & 11342,50 & 186,98 & 25242,50 & $-11,886$ &, 000 \\
Madde65 & 91,33 & 12329,00 & 179,67 & 24256,00 & $-9,638$ &, 000 \\
Madde74 & 83,55 & 11279,00 & 187,45 & 25306,00 & $-11,625$ &, 000 \\
Madde76 & 92,64 & 12507,00 & 178,36 & 24078,00 & $-9,517$ &, 000 \\
Madde78 & 83,71 & 11301,00 & 187,29 & 25284,00 & $-11,562$ &, 000 \\
Madde79 & 88,34 & 11926,50 & 182,66 & 24658,50 & $-10,121$ &, 000 \\
Madde83 & 86,97 & 11741,50 & 184,03 & 24843,50 & $-11,323$ &, 000 \\
Madde87 & 88,40 & 11933,50 & 182,60 & 24651,50 & $-11,093$ &, 000 \\
\hline
\end{tabular}

$* * * \mathrm{p}<.001$

Ölçeğin maddelerinde alt ve üst \%27'lik gruplar arasındaki farkın bulunmasına yönelik hangi testin yapılacağına karar verilmeden önce grupların normal dağılıma sahip olup olmadığı incelenmiştir. Grupların normal dağılım göstermediği belirlenmiş ve parametrik olmayan testlerin uygulanmasına karar verilmiştir. Ölçekteki maddelerin ayırt

ediciliğini belirlemek amacıyla her bir madde için \%27'lik alt ve üst gruplarda bağımsız gruplar t testi yapılmıştır. Yapılan analiz sonucu bütün maddelerde üst $\% 27$ ve alt $\% 27$ 'lik gruplar arasında anlamlı farklılıklar bulunmaktadır $(\mathrm{p}<.001)$. Buna göre ölçekteki her maddenin ölçülmek istenen özelliği ölçmede ayırt edici olduğu söylenebilir.

Tablo 10. Ölçekteki Maddelerin Açımlayıcı Faktör Analizi Sonucunda Faktörlere Göre Dağılımları ve Güvenirlik Katsayıları

\begin{tabular}{|c|c|c|c|}
\hline \multicolumn{2}{|c|}{ Maddenin } & \multirow[b]{2}{*}{ Faktör 1: "Korunma Hakkı" } & \multirow{2}{*}{$\begin{array}{c}\alpha \\
.82 \\
\end{array}$} \\
\hline Eski No & Yeni No & & \\
\hline 51 & 1 & Her çocuk biricik ve özeldir. & \\
\hline 53 & 2 & İstemediğim kişinin bana dokunmaması için çevremdeki yetişkinler tarafindan korunurum. & \\
\hline 54 & 3 & Yetişkinler beni zararlı alışkanlıklardan uzak tutarlar. & \\
\hline 52 & 4 & Yaşam alanlarımda yetişkinler tarafından gerekli hijyen sağlanır. & \\
\hline 87 & 5 & Devlet, beni ve çocuk olarak sahip olduğum tüm hakları korur. & \\
\hline 46 & 6 & Bana aile bağları ile ilgili gerekli ve yeterli bilgi verilir. & \\
\hline 60 & 7 & Haklarımı korkmadan, özgürce talep edebilir ve korurum. & \\
\hline 57 & 8 & Çocuk hakları büyükler tarafından bilinir ve bana anlatılır. & \\
\hline 83 & 9 & Okulda ve evde yetişkinler tarafindan önemsenirim. & \\
\hline \multirow[t]{2}{*}{16} & 10 & Zarar görebileceğim durumlarda çevremdeki yetişkinler tarafindan korunurum. & \\
\hline & & Faktör 2: “Özgür Yaşama Hakkı” & .67 \\
\hline 79 & 11 & İstersem toprakla oynayabilirim. & \\
\hline 78 & 12 & İstediğimde şiir okuyabilir, şarkı söyleyebilir, resim yapabilirim. & \\
\hline 65 & 13 & Hayvanları sever ve istediğimde dokunabilirim. & \\
\hline 76 & 14 & İstediğimde öğretmenime, anneme, babama dokunup, onları sevebilirim. & \\
\hline \multirow[t]{2}{*}{74} & 15 & Oynayacağım oyunu ve oyuncağı kendim belirlerim. & \\
\hline & & Faktör 3: "Bilgi Edinme ve Görüş Bildirme Hakkı" & .62 \\
\hline 13 & 16 & Bir gezi planlanacağı zaman fikrim alınır. & \\
\hline 12 & 17 & Yeni alınan bir eşyanın yeri belirlenirken fikrim alınır. & \\
\hline 2 & 18 & Yetişkinler beni ilgilendiren konularda karar alırken benim fikrimi sorarlar. & \\
\hline
\end{tabular}

Açımlayıcı faktör analizi sonucunda ölçek nihai halini almış ve maddeler yer aldıkları faktörlere göre sıralanmış ve yeniden numaralandırılmıştır. Faktörlerin ve ölçeğin iç tutarlılık katsayıları birinci faktör için .82; ikinci faktör için .67; Üçüncü faktör için .62 olarak hesaplanmıştır. Ölçeğin tamamının iç tutarlılık katsayısı ise .83 olarak hesaplanmıştır.

Geliştirilecek bir ölçekte iç tutarlık kat sayıları:

$.00 \leq \alpha<.40$ ise ölçek güvenilir değildir.

$.40 \leq \alpha<.60$ ise ölçek düşük güvenirliktedir.

Tablo 11. Doğrulayıcı Faktör Analizi Sonuçları
$.60 \leq \alpha<.80$ ise ölçek oldukça güvenilirdir.

$.80 \leq \alpha<1.00$ ise ölçek yüksek güvenirlikte bir ölçektir (Tekez, 2004).

Bir ölçekte bulunan güvenirlik kat sayısının 1'e yakın bir değer olması ölçeğin oldukça güvenilir bir ölçme aracı olduğunu gösterebilir (Tavşancıl, 2002). Ölçeğin alt boyutlarının ve tamamının iç tutarlılık katsayıları incelendiğinde ölçeğin tamamı için yüksek güvenirliğe sahip bir ölçek olduğu söylenebilir.

\begin{tabular}{ll}
$\mathbf{X}^{2}$ & 246,44 \\
Sd & 132 \\
RMSEA & 0,04 \\
GFI & 0,95 \\
AGFI & 0,93 \\
\hline
\end{tabular}




\begin{tabular}{ll}
\hline SRMR & 0,05 \\
NNFI & 0,97 \\
NFI & 0,95 \\
CFI & 0,97
\end{tabular}

Doğrulayıcı faktör analizi kapsamında, $\chi 2$ / df (ki-kare / serbestlik derecesi) değeri 1,87 olarak bulunmuştur. $\mathrm{Bu}$ sonuç modelin mükemmel uyuma sahip olduğunu göstermektedir. Bu değerin 2 veya altında bir değer olması modelin mükemmel bir model olduğunu 5 veya daha altında değer alması ise modelin kabul edilebilir bir uyum iyiliğine sahip olduğunu gösterir (Sümer, 2000).

Modelin RMSEA değeri 0,04 olarak bulunmuştur. RMSEA değerinin 0,05 ' ten küçük veya eşit olması mükemmel uyumu, 0,08' den küçük olası ise iyi bir uyuma işaret eder (Çokluk vd., 2014). Bu çerçevede, yapılan analiz sonucu elde edilen uyum indeksi, modelin mükemmel uyuma sahip olduğu ifade edilebilir. Modele ait GFI ve AGFI uyum indeksleri incelendiğinde, GFI' nın 0,95, AGFI' nın ise 0,93 olduğu görülmektedir. GFI ve AGFI indekslerinin $0,95^{\prime}$ in üzerinde olmas1 mükemmel uyuma, 0,90' in üzerinde olması ise iyi uyuma karşılık gelmektedir (Çokluk
0,97

0,95

0,97 görülmektedir. SRMR uyum indeksinin 0,05 olduğ görülmektedir. SRMR indeksinin $0,05^{\prime}$ in altında olmasi mükemmel uyuma, $0,08^{\prime}$ in altında olması ise iyi uyuma ve 0,10 ' un altında olması ise zayıf uyuma işarettir (Çokluk ve diğerleri, 2014). Bu kapsamda elde edilen SRMR değerinin mükemmel uyuma karşılık geldiği söylenebilir.

Son olarak yapılan analizde NFI, NNFI ve CFI uyum indeksleri incelendiğinde, NFI'nın 0,95, NNFI'nın 0,97 ve CFI'nın 0,97 değerine sahip olduğu görülmektedir. NFI, NNFI ve CFI indekslerinin 0,95' in üzerinde olması mükemmel uyuma, 0,90' in üzerinde olması iyi uyuma karşılık gelmektedir (Çokluk vd., 2014). Buna göre, yapılan analiz için NFI, NNFI ve CFI değerlerinin mükemmel uyuma sahip oldukları görülmektedir.

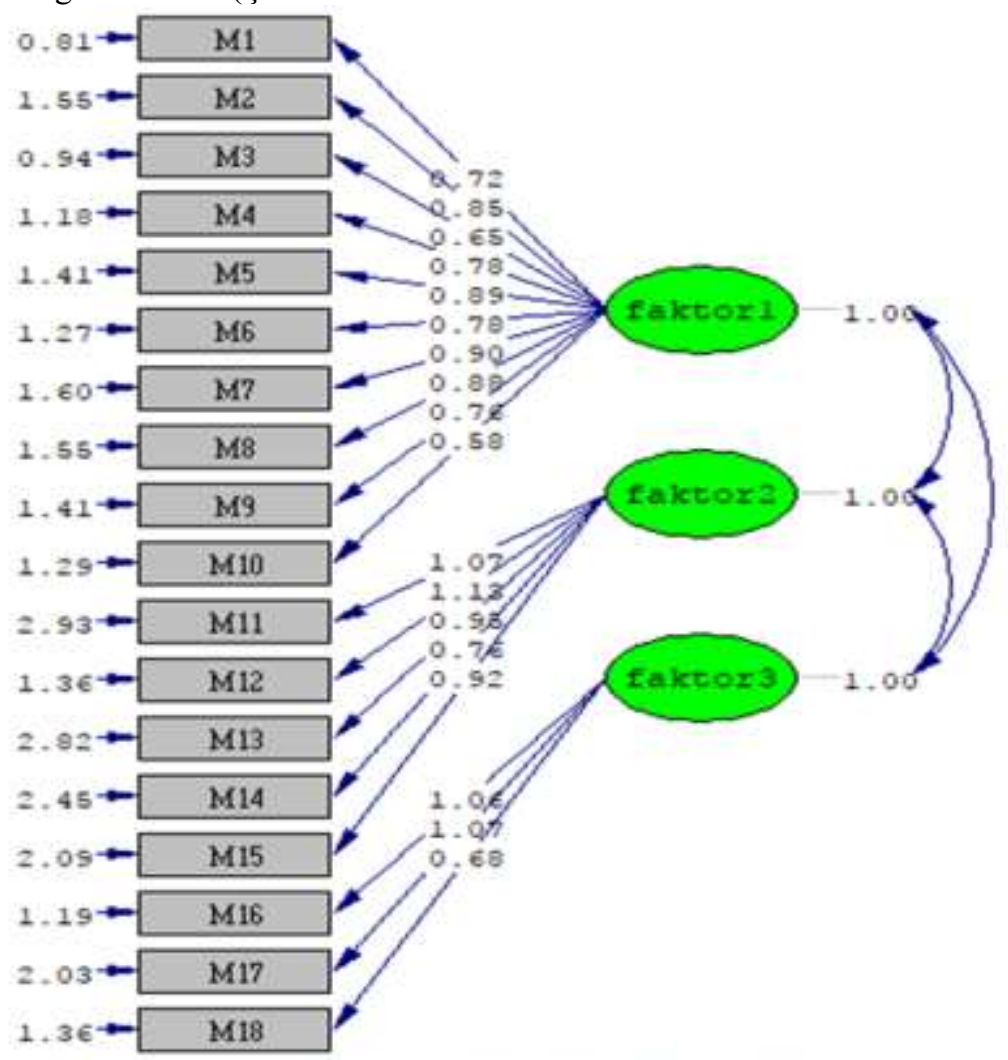

Chi-square=246.44, $d f=132, \quad p-v a l u e=0.00000$, RMSEA=0.042

Şekil 3. Doğrulayıcı Faktör Analizi Uyum Modeli Bulguları

Doğrulayıcı faktör analizi uyum modeli bulguları, faktör yapısının uyumlu olduğunu göstermektedir. Öngörüldüğü üzere aynı maddelerin üç faktör altında toplandığı ve

\section{Sonuç ve Öneriler}

Araştırmanın amaçları doğrultusunda elde edilen bulguların analiz edilmesinin ardından şu sonuca varılmıştır:

Çalışma kapsamında ilkokul 3. ve 4. sınıf öğrencilerinin çocuk hakları konusundaki bilinç düzeylerini belirlemeye yönelik olarak toplamda 3 boyut ve 18 maddeden oluşan bir ölçeğin tamamını bu faktörlerin birlikte yordadığı görülmüştür.

ölçek geliştirilmiştir. Yapılan açımlayıcı ve doğrulayıcı faktör analizleri sonucu geçerliği (kapsam, görünüş, yapı, ıraksak ve yakınsak) ve güvenirliği (iç tutarlılık, \%27'lik alt grup üst grup ortalamaları) sağlanmış, ilkokul 3. ve 4. sınıf öğrencilerinin çocuk hakları konusundaki bilinç düzeylerini belirlemeye yönelik olarak kullanılabilecek bir ölçek geliştirilmiştir. 
Araştırmanın amaçları doğrultusunda elde edilen bulguların analiz edilmesinin ardından şu önerilerde bulunulabilir:

(i) Araştırma Tokat İli kapsamında yapılmıştır. Türkiye genelinde daha geniş kapsamlı bir katılım ile başka bir ölçek geliştirilebilir.

(ii) Araştırma ilkokul 3. ve 4. sınıf öğrencilerine yönelik olarak gerçekleştirilmiştir. Yapılacak araştırmalar sadece 3. sinif, sadece 4. sinıf ya da ortaokul, lise, önlisans, lisans öğrencilerine yönelik olarak gerçekleştirilebilir.

(iii) Ülkemizdeki lisans eğitim seviyesi de dikkate alınarak, öğrencilerimizi yetiştiren öğretmenlerimize yönelik bir çalışma yapılabilir.

(iv) Ülkemizde çocuk hakları konusunda yapılan araştırmalar ve özellikle ölçek geliştirme çalışmaları çok kısıtlı olduğu görülmektedir. Bu sebeple çocuk hakları konusunda yapılacak olan araştırmalara yönelik teşvikler sağlanabilir.

(v) Araştırma kapsamında geliştirilen ölçek çocukların çocuk hakları konusundaki bilinç düzeyini evdeokulda ve sizin için önemi olarak üç farklı kategoride ölçmektedir. Yapılacak diğer çalışmalarda farklı alanlarda ve kategorilerde ölçüm yapilabilir.

\section{Kaynakça}

Akgül, M. Ş. (2015). İlkokul öğrenci velilerinin çocuk haklarına ilişkin görüşlerinin değerlendirilmesi (Yüksek Lisans Tezi).Yükseköğretim Kurulu Ulusal Tez Merkezi'nden edinilmiştir. (Tez No. 395149).

Akyüz, E. (2000). Çocuğun haklarının ve güvenliğinin korunması. Ankara: Milli Eğitim Yayınevi.

Akyüz, E. (2013). Çocuk hukuku çocukların haklarl ve korunması(Genişletilmiş 3. baskı). Ankara: Pegem Akademi Yayınevi.

Büyüköztürk, Ş. (2002). Faktör analizi: Temel kavramlar ve ölçek geliştirmede kullanımı. Kuram ve uygulamada eğitim yönetimi, 32(32), 470-483.
Büyüköztürk, Ş. (2008). Sosyal bilimler için veri analizi el kitabı. Ankara: PegemA Yayıncılık.

Büyüköztürk, Ş. (2013). Sosyal bilimler için veri analizi el kitabı istatistik, araştırma deseni spss uygulamaları ve yorum (Genişletilmiş 18. baskı). Ankara: PegemA Yayıncilık.

Büyüköztürk, Ş., Çakmak, E., Akgün, Ö. E., Karadeniz, Ş. ve Demirel, F. (2008). Bilimsel araştırma yöntemleri. Ankara: Pegem Akademi.

Cılga, İ. (2001). Demokrasi insan hakları kültürü ve çocuk hakları. Milli Eğitim Dergisi, 151(16.02), 2011.

Çokluk, Ö. Şekercioğlu, G. ve Büyüköztürk, Ş. (2014). Sosyal bilimler için çok değişkenli istatistik spss ve lisrel uygulamaları (3. Baskı). Ankara: Pegem Akademi

Franklin, B. (1993). Çocuk hakları. İstanbul: Ayrıntı Yayınları.

Gözler, K. (2011). Hukuka giriş, Bursa: Ekin Yayınevi.

İnan, A.N. (1968). Çocuk hukuku. İstanbul: Sistem Yayıncılık.

Rodham, H. (1973). Children under the law. Harvard Educational Review, 43(4), 487-514.

Serozan, R.(2005). Çocuk hukuku, İstanbul: Vedat Kitapç1lık.

Sümer, N. (2000). Yapısal eşitlik modelleri: Temel kavramlar ve örnek uygulamalar. Türk Psikoloji Yazılarl, 3(6), 49-74

Şişman, Y. (2006). Sokakta çalışan çocukların yaşam koşulları ve gelecek beklentileri. Anadolu Üniversitesi Sosyal Bilimler Dergisi, 6(2), 251-275

Tavşancıl, E. (2002). Tutumların ölçülmesi ve SPSS ile veri analizi. Ankara: Nobel Yayınları.

Tekez, (2004). Genel lise öğrencilerinin öğrenme stilleri (Yüksek Lisans Tezi).Yükseköğretim Kurulu Ulusal Tez Merkezi'nden edinilmiştir. (Tez No. 143984).

Yurdugül, H. (2005). Ölçek geliştirme çalışmalarında kapsam geçerliği için kapsam geçerlik indekslerinin kullanılması. XIV. Ulusal Ĕ̈itim Bilimleri Kongresi, 1, 771-774. 
EKLER:

\section{EK 1: ÇOCUK HAKLARI ÖLÇEĞII}

\begin{tabular}{|c|c|c|c|c|c|c|c|c|c|}
\hline \multirow[b]{2}{*}{ ÇOCUK HAKLARI } & \multicolumn{3}{|c|}{ Okulda } & \multicolumn{3}{|l|}{ Evde } & \multicolumn{3}{|c|}{$\begin{array}{l}\text { Sizin İçin } \\
\text { Önemi }\end{array}$} \\
\hline & 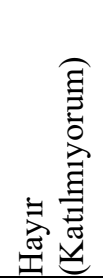 & 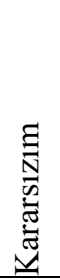 & 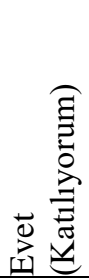 & 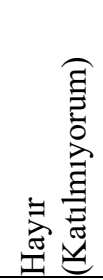 & 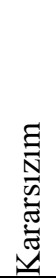 & 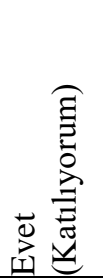 & 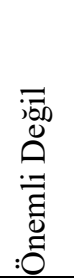 & 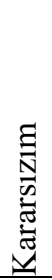 & $\begin{array}{l}: \bar{E} \\
: 0 \\
: 0\end{array}$ \\
\hline 1. Her çocuk biricik ve özeldir. & & & & & & & & & \\
\hline $\begin{array}{l}\text { 2. İstemediğim kişinin bana dokunmaması için } \\
\text { çevremdeki yetişkinler tarafından korunurum. }\end{array}$ & & & & & & & & & \\
\hline $\begin{array}{l}\text { 3. Yetişkinler beni zararlı alışkanlıklardan uzak } \\
\text { tutarlar. }\end{array}$ & & & & & & & & & \\
\hline $\begin{array}{l}\text { 4. Yaşam alanlarımda yetişkinler tarafından gerekli } \\
\text { hijyen sağlanır. }\end{array}$ & & & & & & & & & \\
\hline $\begin{array}{l}\text { 5. Devlet, beni ve çocuk olarak sahip olduğum tüm } \\
\text { hakları korur. }\end{array}$ & & & & & & & & & \\
\hline $\begin{array}{l}\text { 6. Bana aile bağları ile ilgili gerekli ve yeterli bilgi } \\
\text { verilir. }\end{array}$ & & & & & & & & & \\
\hline $\begin{array}{l}\text { 7. Haklarımı korkmadan, özgürce talep edebilir ve } \\
\text { korurum. }\end{array}$ & & & & & & & & & \\
\hline $\begin{array}{l}\text { 8. Çocuk hakları büyükler tarafindan bilinir ve bana } \\
\text { anlatılır. }\end{array}$ & & & & & & & & & \\
\hline $\begin{array}{l}\text { 9. Okulda ve evde yetişkinler tarafindan } \\
\text { önemsenirim. }\end{array}$ & & & & & & & & & \\
\hline $\begin{array}{l}\text { 10. Zarar görebileceğim durumlarda çevremdeki } \\
\text { yetişkinler tarafindan korunurum. }\end{array}$ & & & & & & & & & \\
\hline 11. İstersem toprakla oynayabilirim. & & & & & & & & & \\
\hline $\begin{array}{l}\text { 12. İstediğimde şiir okuyabilir, şarkı söyleyebilir, } \\
\text { resim yapabilirim. }\end{array}$ & & & & & & & & & \\
\hline 13. Hayvanları sever ve istediğimde dokunabilirim. & & & & & & & & & \\
\hline $\begin{array}{l}\text { 14. İstediğimde öğretmenime, anneme, babama } \\
\text { dokunup, onları sevebilirim. }\end{array}$ & & & & & & & & & \\
\hline $\begin{array}{l}\text { 15. Oynayacağım oyunu ve oyuncağ } 1 \text { kendim } \\
\text { belirlerim. }\end{array}$ & & & & & & & & & \\
\hline 16. Bir gezi planlanacağı zaman fikrim alınır. & & & & & & & & & \\
\hline $\begin{array}{l}\text { 17. Yeni alınan bir eşyanın yeri belirlenirken fikrim } \\
\text { alınır. }\end{array}$ & & & & & & & & & \\
\hline $\begin{array}{l}\text { 18. Yetişkinler beni ilgilendiren konularda karar } \\
\text { alırken benim fikrimi sorarlar. }\end{array}$ & & & & & & & & & \\
\hline
\end{tabular}

